DOI: 10.7596/taksad.v2i1.202

\title{
The Role of Kurds in the Struggle for the Foundation of Turkish Republic
}

\author{
Suat Zeyrek ${ }^{1}$
}

\begin{abstract}
This article discusses the role of Kurdish tribes during the Turkish Independence War (1918-1922). It shows that despite various manipulations orchestrated by the British government, certain Kurdish groups based in Istanbul refused to collaborate with the British against the Ottoman Empire and thus did not follow a separatist policy. This article is reviewed along the Turkish-British Struggle in the national competition, the national movement in Kurdistan; they are used to describe how the tool they neutralize. During the continuing cutthroat competition, most of the Kurds did not become an instrument to all kinds of British policies. British did not manage to have the Kurds rebel along their imperial interests even though they manipulated the independence of Arabs, Armenian nationalism and Zionism.
\end{abstract}

Keywords: Kurds, Kurdish Tribes, Turkish Independence War, British policies.

\section{Introduction}

Turkish constitutional monarchy, is its centenary, (1908-1918) was affected by hard terms of Montrose Armistice. The period of armistice affected so deeply the social and political life. The political life became active due to the risk of separation and

\footnotetext{
${ }^{1}$ Dr., İstanbul Üniversitesi Atatürk İlkeleri ve İnkılap Tarihi Enstitüsü.
} 
occupation of the country. The Turkish Parliament (Meclis-i Mebusan) was closed down. Several political parties and associations emerged at this period.

Constitutional Monarchy in Turkey was shaken with hard terms of Muros Armistice signed in 1918 between the Ottoman Empire and the Allied Powers. The Turkish Parliament (Meclis-i Mebusan) was closed down, and the risk of occupation, as well as separation, led to the emergence of increasing number of political parties and organizations. The Western powers had been on a consensus to divide the Ottoman Empire, but the question of partition was yet to be resolved, and the Ottoman Empire gained some more time to fight for its survival. Political turbulence in the Empire after the Montrose Armistice, however, showed on-going internal divisions in the state. The government in Istanbul, rebellious minorities and independent resistance forces to the occupation forces were all acting independently, and often against each other. NonMuslim minorities' revolted against the Ottoman government as well despite of the fact that they were granted significant religious and economical rights. In fact, the religious leader of a non-Muslim community in the Ottoman Empire had more power than a religious leader in a Christian state, but these leaders abused their powers, collecting high taxes from their communities. ${ }^{2}$ As can be seen, the Ottoman Empire did not interfere with the internal affairs of the Rum millet to the extent that it did not save ordinary citizens from the coercive rule of the Rum Orthodox Church. ${ }^{3}$

During the period of founding a new national government, England worked hard to undermine social order and security in the Empire, which would in turn ease the way for them to provoke minority communities against the government. As a result of the English occupation on the Arab lands and the separatist policy of certain Arab tribes, the multi-national structure of the Ottoman Empire would soon dismantle. Britain fought in the First World War against the Ottoman Empire, organized and supported the Assyrians and Nestorians. As a matter of fact Britain's main purpose was to bring Kurdish tribes into the fold of the Allied Powers. Captain Gracey was sent to the region with this mission. ${ }^{4}$ Even though the British won the battle in the First World War, Armenians could not fully reach their goals. After the armistice, the British manipulated

\footnotetext{
2 İlber Ortaylı, “Osmanlı İmparatorluğu'nda Millet”, Tanzimat'tan Cumhuriyete Türkiye Ansiklopedisi (TCTA), C. 4, İstanbul, İletişim, 1985, pp. 996-997.

3 Stanford Shaw, “Osmanlı İmparatorluğu'nda Azınlıklar Sorunu”, Tanzimattan Cumhuriyete Türkiye Ansiklopedisi, (TCTA), C, 4, pp. 1003.

${ }^{4}$ Bülent Özdemir, Süryanilerin Dünü Bugünü, Ankara, TTK, 2009, pp. 82.
} 
the Armenians. Armenians could have achieved their targets, if the Kurds had abandoned their homeland. The promises of the British to the Armenians and other separatist elements thoroughly approached the Kurds to the Turks.

There were various Ottoman and Arabian intellectuals who fought against this separation. Although intellectuals such as Raşit Rıza (1865-1935) defended the Arab nationalism, they did not advocate separation. ${ }^{5}$ The Ottoman Empire had no chance to survive after the separation, and Mustafa Kemal, aware of this reality, stated in a telegram he sent to Uceymi Pasha of Iraq: “Two valuable nations, the Turks and the Arabs, were so weak as a result of separation. We had to come together to struggle for the independence of the Muslim community of Mohammed worldwide". 6

Moreover, Mustafa Kemal Pasha stated at the opening speech of Erzurum Conference that there was a plan to make the Arab nation a servant and that people revolted against the coercive government of British in the land of Iraq and Arabia. He added that the revival would continue everywhere ${ }^{7}$. These comments also show that he had no desire to re-establish a political control over the Arab lands and was ready to support their independence. When Mustafa Kemal explained the will to form a national resistance after Erzurum and Sivas congresses, he also warned the Syrian Arabs and talked about of the violation of boundaries drawn in Syrian Agreement (Anglo-French Treaty). ${ }^{8}$ Indeed, in a telegram by Colonel Meinertzhagen to Lord Curzon on September 23, 1919: "Mustafa Kemal is trying to expel the aliens from his nation by uniting the Turks, Arabs and Kurds" "9 The British did not hide their concerns about the fact that the Project of Greater Armenia could eventually lead to a possible Turkish - Kurdish cooperation. Lord Curzon, as warned by Chaltrop: "It is possible that Kurds might approach the Kemalists in accordance with the patriotic decisions of the Erzurum Congress". ${ }^{10}$

Despite of the pressure from the French forces, in a telegram dated 24.11920 Ali Fuat Pasha argued that Syrian Arabs decided not to separate from the Ottoman Empire

\footnotetext{
5 İlber Ortaylı, “Osmanlı İmparatorluğu'nda Arap Milliyetçiliği”, TCTA,, C, 4, pp. 1034.

6 Nimet Arsan, Atatürk'ün Söylev ve Demeçleri, C, I, Ankara, 1961, pp.. 3-5.

7 Harp Tarihi Vesikaları Dergisi, (HTVD), Sayı: 2, Vesika: 14.

8 Nimet Arsan, Atatürk'ün Tamim, Telgraf ve Beyannameleri, C. 4, Ankara, 1964, pp. 119-120.

9 Erol Ulubelen, Íngiliz Gizli Belgelerinde Türkiye, İstanbul, Cumhuriyet, 2006, p. 179. (Belge no:288)

10 M.S. Lazarev, Emperyalizm ve Kürt Sorunu (1917-1923), (Çev. Mehmet Demir), Ankara, Özge, 1989, pp. 163-164.
} 
by any means and to join national struggle in Anatolia founding organized forces in Aleppo. ${ }^{11}$ Mustafa Kemal Pasha, in January 1920, also agreed an offer for founding a confederation between Turkey, Iraq and Syria. He wanted to act together with Arab forces, destroying French and Armenian forces, who had worked hard to separate the Turks and Arabs.

The most complicated document about the territorial aims of Turkey is "Misak-i Milli"; its first article demonstrates this complexity. It starts with a commitment to preserve the unity of the Ottoman Empire, but also notes that the destiny of the lands where the Arabs were majority and occupied by alien forces would be decided according to a referendum. Due to the misunderstandings and confusions in the Misak-1 Milli, Mustafa Kemal Pasha had some statements in 23.2.1920. He added that İsmet Bey would have been responsible for communicating with Arabs and Arabia would not have been excluded from the Ottoman boundaries as Misak-1 Milli had defined the Ottoman lands as Muslims lands. ${ }^{12}$

Mustafa Kemal Pasha says that before 1924 Syrian, Iraqi, and Arabian views on this issue were so different. He states that they did not want to be part of Ottoman Empire and they viewed British and France like saviours. ${ }^{13}$ Experiencing the British and French rule in Syria and Iraq, they wanted to join the Ottoman unity again. Both Syrians and Iraqis began to believe they would be captives after their separation from Ottoman Empire. Thus, Syria Conference in Damascus ( $2^{\text {nd }}$ July 1919) decided to struggle for independence against France. ${ }^{14}$ Answering the Syrian and Iraqi demands to be part of the Ottoman unity, Mustafa Kemal Pasha stated: "First, you should establish your own power and gain independence; then there will not be any obstacle for unity'. ${ }^{15}$ Although Syria and Iraq were in close touch with the resistance movement in Anatolia, Arabia was acting as if a British province. England government helped Sherif Hussain, the king of Hijaz, and the Amir of Najad, Ibn Saud. British made use of the struggle between these two rulers, and Ibn Sa'ud won the struggle, sending Hussain into exile.

${ }^{11}$ Ali Fuat Cebesoy, Milli Mücadele Hatıraları, İstanbul, 1953, pp. 289.

${ }^{12}$ HTVD, Sayı: 15, Vesika No: 402.

13 HTVD, Sayı: 15, Vesika No: 402.

${ }_{15}^{14}$ TBMM G.C.Z., C, I, İstanbul, 1999, pp. 2.

${ }^{15}$ Bülent Tanör, Türkiye'de Yerel Kongre İktidarları, İstanbul, 1992, pp. 18-19.

${ }^{16}$ TBMM GCZ, C: I, p. 3. 
That no other country could oppose the British policy in the region they established a total control over the region. ${ }^{16}$

\section{The Situation of Kurds}

England provoked the Kurds against the Ottoman government after the Montrose; during the World War I strategic plans were built to provoke the Arabs, whereas during the armistice, the British diplomacy focused its attention on the Kurds. This was part of their plan to prevent the foundation of Turkish government in Anatolia, and some Kurdish groups, if not all, collaborated with the British government and wanted to found an independent Kurdish state as a buffer zone in the region. ${ }^{17}$ Various Kurdish associations were founded in Istanbul in 1918-9 with the help of British such as the Association of Kurdistan Teali (AKT), which was the most salient one among them.

Actually, the Ottoman government accepted the foundation this association based and Tevfik Pasha wanted Kurds to work against the Great Armenia project of the Entente Powers. ${ }^{18}$ Yet this organization stated that they had waited patiently until the end of Paris Conference, but now would fight against the resistance movement in Anatolia as the clashes in Malatya had been an insult to the honour of Kurdish nation. The declaration also underlined that they would not accept any other government other than the British. ${ }^{19}$

Kurdistan Teali also wrote letters to the leaders of Kurdish tribes, who had declared their allegiance to the Ottoman government, explaining that they undermined the Kurdish movement, yet the majority of the Kurdish tribe had a clear idea about the real purpose of the British government. These tribes, however, were not as quick as the pro-British Kurdish groups in organizing their forces; a Kurdish organization, supporting National Resistance, was established but the common perception was that pro-British organizations represented the Kurds. Because of the social order based on tribal structure and division among the Kurdish tribes, there was no strong authority to

17 David Fromkin, Barışa Son Veren Barış, İstanbul, 1989, pp. 422-424.

18 Sina Akşin, İstanbul Hükümetleri ve Milli Mücadele, C. II, İstanbul, Cem, 1992, pp. 111.

19 Tarık Zafer Tunaya, Türkiye'de Siyasal Partiler, C.II, İstanbul, 1986, pp. 188-189.

${ }^{20}$ Sina Akşin, a.g.e., II, pp. 113. 
represent the majority. ${ }^{20}$ This situation made it more arduous for the British government to work with the Kurdish tribes in the region, and they chose to collaborate with the Kurdish organizations in Istanbul. ${ }^{21}$

Seyyid Abdulkadir, the leader of AKT, founded on December 17 1918, was in a close contact with British General Noel. Following the spread of rumours about the annexation of Eastern Anatolia by the Armenians Eastern Anatolia Defence Organization warned the AKT and asked for cooperation. However, this offer was not accepted as the leaders of this association did not hide their desire to establish an independent Kurdistan. ${ }^{22}$ The foundation of an independent Kurdish state, under the British protection, was the goal of the most of the AKT members. The Ottoman government took a swift decision to organize Encumen-i Mahsus, so that they warned the inhabitants of region against the AKT. ${ }^{23}$ Being the inspector of the Third Army, Mustafa Kemal Pasha stated: "The AKT did not represent the Kurds, this club was just an attempt of beggars". Diyarbakır Kurdish Club, a British initiative, was shot down, and its members were prosecuted. ${ }^{24}$

Some significant events took place in the Eastern and Southeastern Anatolia while the government struggled against that Kurdish clubs; inhabitants of Mardin registered their faith by sending a diplomatic note to Grand Vezir and demanded the government to intervene in the region. ${ }^{25}$ Likewise, the inhabitants of Erzurum $\left(18^{\text {th }}\right.$ April 1919) and the inhabitants of Diyarbakır (25 ${ }^{\text {th }}$ April 1919) stated that they were part of the Ottoman Empire. ${ }^{26}$ England, however, continued to encourage the separation of Kurds; General Noel was a supporter of Kurds and led negative propaganda against the Ottoman Empire. Noel had an interview with Mr. Mahmut, the son of National tribe leader İbrahim Pasha, and said to him that England would help Kurds. However, the leader of tribe argued that Europe supported Armenians seriously, but did not show any interest

\footnotetext{
21 Sina Akşin, a.g.e., II, pp. 112.

22 Türkiye' de bugün de buna benzer bir durum yaşanmaktadır. Kürtleri temsil etmeyen bir örgüt vardır. Kürtler yeniden Türk, Arap ve İran nüfuslarının etkinlik alanlarına yayılmış olmalarından dolayı büyük güçlerin stratejik denkleminin bir yerinde kullanılmaktadır. Bu Kürt sorunu, PKK soğuk savaşın sona erme sürecinin getirdiği dengelerde Türkiye'nin Asya derinliğini tehdit eden bir hale gelmiştir. Bkz. Ahmet Davutoğlu, Stratejik Derinlik, İstanbul: Küre 2001, pp. 437-439.

23 Selahattin Tansel, Mondros'tan Mudanya'ya Kadar, C. I, İstanbul, MEB, 1991, pp. 129-130.

24 BOA, $M V$, No: 216/39.

25 Nimet Arsan, ATTB, 4, pp. 34; Kazım Karabekir, Istiklal Harbimiz, pp. 45-46.

${ }^{26}$ Mim Kemal Öke, Mosul - Kürdistan Sorunu 1918-1926, İstanbul, İz Yayıncılık, 1995, pp. 82.

${ }^{27}$ Mim Kemal Öke, a.g.e., pp. 83.
} 
in the Kurdish independence. ${ }^{27}$ The British support behind the Kurds found its peak in 1919 to the extent that Caltroph remarked: "I wish Noel not to be a so zealous supporter of the Kurds". 28

General Noel tried to win over these tribes by money, but the Kurds and the leaders of Kurdish tribes showed that they will not separate from their Turkish brothers and Ottoman unity under any condition. ${ }^{29}$ The British played on the Kurdish government against the Ottomans, in an attempt to forestall emerging independence movement in Anatolia, yet the Ottoman government asked local government to stand against the provocations of the occupation forces in Urfa. ${ }^{30}$ The British carried out a public survey, asking the inhabitants of Malatya which government, Turk or Kurd, they would prefer; this survey was made public by Mustafa Kemal in Sivas Conference. ${ }^{31}$

Whilst the British provocation in the region continued, still in Europe about Muslims was low. Instead, the Europeans took Armenian territorial claims more serious. The Kurds, who were aware of the pro-Armenian policy of the British, French and Americans, aligned with them. This policy was even under criticism by some of the leading statesman such as Admiral Bristol, who said: "The partitioning of the Ottoman Empire and founding a Turkish rule in a small region in Asia Minor would replicate previous mistakes. If Americans support this policy they would be accomplice in this murder., ${ }^{32}$

America was still under the influence England; an American intelligence report notes: "Turkey aims to destroy the Armenians through Teşkilat-1 Mahsusa forces. Istanbul government helps the Kurdish forces, hoping to undermine the nationalist forces and prevent the foundation of Armenia." ${ }^{33}$ In Erzurum Congress it became more obvious that the Kurds would not collaborate with the British; a declaration was released after the Sivas Congress emphasizing that the Turks and Kurds were inseparable from each other, and will live together forever ${ }^{34} \mathrm{~A}$ similar message, saying

\footnotetext{
${ }^{28}$ Mim Kemal Öke, a.g.e., pp. 86.

${ }^{29}$ Mim Kemal Öke, a.g.e., pp. 98.

${ }^{30}$ Nimet Arsan, a.g.e., pp. 43.

31 BOA, $M V$, Dosya no: 217, Gömlek no:80.

${ }^{32}$ Hayri Mutluçă̆, "Sivas Kongresi'nin Tutanak ve Kararları, VI", Belgelerle Türk Tarihi Dergisi, (BTTD) Say1: 67-68, 1973.

${ }_{33}$ Orhan Duru, Amerikan Gizli Belgelerinde Türk Kurtuluş Yılları, İstanbul, 1978, pp. 82.

34 Orhan Duru, a.g.e., pp. 87.

35 Irade-i Milliye, 21 Eylül 1919.
} 
the Kurds would be a part of the Ottoman state, was given in the Amasya meeting. ${ }^{35}$ In his memoranda to General Harbord, Mustafa Kemal Pasha had noted that the Kurds were aware of the British plots orchestrated by Colonel Noel in the region; indeed Noel run similar operations in Malatya as well.

The British tried to show every revolt in Anatolia as a Kurdish revolt, or every government sanction as a sanction against the Kurds. They tried to show that the arrest of a person by the commander of Central Armies, Nurettin Pasha, a Kurdish question. Yet this event had nothing to do with the Kurdish question. ${ }^{36}$ One week before his dismissal Nurettin Pasha spoke to the press and said: "Thousands of Kurdish volunteers fight against the Greeks', 37 Confirming Nurettin Pasha, the Kurdish tribes in the Eastern Anatolia declared their commitment to the Kuvay-1 Milliye, and that the Kurdish tribes were ready for every sacrifice to save the Ottoman unity. ${ }^{38}$

The attitude of the Kurdish tribes in Diyarbakır was the same; Milli Aşireti and Karakecili tribes were to join their forces and stand against the occupation armies. ${ }^{39}$ The Kurdish group representatives in Diyarbakır, Mosul and Bitlis re-confirmed their commitment to the National Struggle in $1921^{40}$; in the regional press published we see such headings as "Turkishness and Kurdishness is an inseparable family". ${ }^{41}$ Many Kurds considered the separation from the Ottoman Empire being subjugated to the Armenian control in the region; Kurdish tribes, therefore, fought hard to defend their rights against the Kurdish clubs and organizations. In the Paris Conference they reiterated that they would not leave the Ottomans and Sherif Pasha was not eligible to represent the Kurds and was a traitor. Facing this resistance from the Kurdish tribes Amiral Webb noted that Serif Pasa was away from his country and not in a position to represent the Kurds. ${ }^{42}$ Mustafa Kemal Pasha was keen to unify the leaders of Kurdish tribe leaders in the National Struggle, and he helped some tribe leaders to take their places in the parliament. ${ }^{43}$ Yusuf Ziya Bey, a Kurdish leader, became a permanent TBMM member as a deputy from Bitlis.

${ }^{36}$ Şerafettin Turan, Türk Devrim Tarihi, 2. Kitap, Ankara 1992, pp. 32.

37 Tevhid-i Efkâr, 17 Teşrin-i sani 1921.

38 Tevhid-i Efkâr, 10 Teşrin-i sani 1921.

39 Tevhid-i Efkâr, 1 Kanun-i evvel 1919.

40 Tevhid-i Efkâr, 3 Kanun-i evvel 1919.

41 Ikdam, 6 Mayıs 1921.

42 Irade-i Milliye, 5 Kanun-i evvel 1920.

43 Sina Akşin, a.g.e., II, pp. 112.

44 Andrew Mango, Atatürk, İstanbul, Sabah, 1999, pp. 320. 
British government raised the question of Kurdistan again in the London Conference. Bekir Sami Bey, however, claimed that there was no Kurdish question as there were deputies in the TBMM from the Kurdish regions, and the Kurds and Turks would share the same destiny ${ }^{44}$. Learning that the Kurdish issue was discussed in the London Conference the leaders of Kurds in Van, sending a telegram to the TBMM, made it clear that the deputies in the TBMM had a legitimate right to represent them and only the TBMM delegation could represent them in London. ${ }^{45}$ Many Kurdish tribes and religious scholars (Ulema) sent a telegraph to the TBMM saying that we did not want Kurdishness as a separate entity in the borders of Misak-1 Milli; the destiny of Kurdishness and Turkishness is the same, those Kurds intending to separate from the Ottoman entity would not be regarded as part of their nation $?^{46}$ The Arab tribes in Adana region sent telegrams to the TBMM reiterating their loyalty to the TBMM. ${ }^{47}$

During the National Struggle certain developments encouraged the Kurdish organizations and the British government; they expected to see the application of the Sevr Treaty. Yet in time the National Struggle gained widespread acceptance in international domain and gathered stronger domestic popular support. The British government raised this issue again in the Lozan Conference and released Sheikh Mahmut, who had been arrested in Suleymaniye, assigning him the leadership of independent Kurdish government. Sheikh Mahmut as a surprise to the British, secretly declared his allegiance to the TBMM. ${ }^{48}$. Although this information was conveyed to Ismet Pasha, as a result of their threatening reports Ismet Pasha concluded that: it would be better to finalize this issue "through peaceful negotiations", ${ }^{49}$ During the conference the most serious issue for the British was the question of Mosul; the basic reason behind the British demands about the Kurdish independence was to acquire Mosul.

The American, having the observer status in the conference, demanded that Turkey should give up Mosul. Japan and Italy had the same opinion; in other words the Mosul question became the hottest topic in the conference. Ismet Pasha, the head of Turkish delegation, opted for giving up Mosul, whereas Riza Nur, the second head of the Turkish delegation, advocated that they should not give up Mosul at this stage.

\footnotetext{
45 Şerafettin Turan, a.g.e., pp. 245.

46 TBMM, ZC, C: 9, Ankara 1954, pp. 141.

47 TBMM, ZC, C: 9, pp. 133.

48 TBMM, ZC, C: 9, pp. 132.

49 Bilal Şimşir, Lozan Telgrafları I (1922-1923), Ankara, TTK, 1990, pp. 189.

${ }^{50}$ Bilal Şimşir, a.g.e., pp. 288.
} 
Hasan Saka, the other member of the delegation, underlined that Mosul is the key to the peace and he could not decide on this question on his own. ${ }^{50}$

In the Lozan Conference Lord Curzon argued that the TBMM representatives did not represent the Kurds, as they were ignorant of the issue, and that they were appointed by Mustafa Kemal Pasha. Facing these accusations Yusuf Ziya Bey (Bitlis Deputy) made a speech at TBMM on 25 October 1923, in this speech it was striking that he said

" Our delegation in Lozan could not answer these accusations in Lozan properly" ${ }^{51} \mathrm{He}$ continued: "We are the real representatives of the people of Kurdistan; we are here not by appointment but elections. Kurdish people participated in these elections without any coercion; if the Kurds really wanted to separate they would not participate. The British worked with their gold, but the Kurds did not change their choices. They had the same goal with their Turkish brothers. We want Mosul and will take it. Europeans should not act so slow in giving us our rights. If it is necessary, Kurds will dig new wells from blood next to the British oil wells.",52

\section{Conclusion}

The dissolution of the Ottoman Empire was a result of the WW I, but it also was related to the separation of constituent communities from the Empire. The Ottoman unity had been composed of Turkish, Arab and Kurdish Muslims; this structure ended with the separation of Arabs. The foundation of a national state in Anatolia was conditioned upon the political stance of the Kurd in the region. Therefore, the British government wanted to manipulate the Kurds and pledged them the foundation of an independent Kurdistan after the Montrose armistice. They aimed to organize the Kurds through various organizations founded in Istanbul and south-eastern Anatolia. Underlying these plans was to secure their control across the oil fields in Iraq and found a buffer zone with the Ottoman state. Lausanne Conference significance for the British proved that the Kurds. Lausanne Conference proved that the Kurds were not important for the British. The whole purpose of the British was to give the Armenians a homeland. Indeed, the Near East Relief Organization established by the financial contribution of the Rocfeller Foundation distributed its aids among the Armenians, Assyrians, and Arab

${ }^{51}$ Bilal Şimşir, a.g.e., pp. 449-450.

52 TBMM, ZC, C: 26, Ankara, 1960, pp. 505.

${ }^{53}$ TBMM, ZC, C: 26, pp. 505-506. 
Christians in 1919. Yet the Kurds stood firm facing these plans; the struggle for national independence was won with the collaboration of Turkish and Kurdish forces and the Turkish Republic was founded. Mosul region was lost to the British, but the Kurdish people were convinced to stay in the new Turkish state. Kurds were not close to the policy of separatism during the years of World War I as well as the Period of National Struggle in spite of all sorts of incentives and incitements. Therefore the British entered into a kind of behaviour of revenge against the Kurds with various methods during the period of National Struggle. As of today, it could be said that the problems experienced under the name of the Kurdish issue in Turkey inherited from the past and have a historical background. 


\section{References}

Başbakanlık Osmanlı Arşivi, (BOA), Meclis-i Vükela (MV), Dosya no: 216, Gömlek no:39.

$B O A, M V$, Dosya no: 217, Gömlek no: 80 .

Türkiye Büyük Millet Meclisi, Gizli Celse Zabıtları, (TBMM GCZ), C: I, İstanbul, 1999.

TBMM, Zabıt Ceridesi, C: 26, Ankara, 1960.

TBMM, ZC, C: 9, Ankara 1954.

Harp Tarihi Vesikaları Dergisi, (HTVD), Say1: 15, Vesika No: 402.

HTVD, Sayı: 2, Vesika: 106.

İkdam, 6 May1s 1921.

Irade-i Milliye, 21 Eylül 1919.

Irade-i Milliye, 5 Kanun-i evvel 1920.

Tevhid-i Efkar, 1 Kanun-i evvel 1919.

Tevhid-i Efkar, 10 Teşrin-i sani 1921.

Tevhid-i Efkar, 17 Teşrin-i sani 1921.

Tevhid-i Efkar, 3 Kanun-i evvel 1919.

Akşin, Sina, İstanbul Hükümetleri ve Milli Mücadele, C: II, İstanbul: Cem, 1992.

Arsan, Nimet, Atatürk'ün Söylev ve Demeçleri, C: I, Ankara, 1961.

Arsan, Nimet, Atatürk'ün Tamim, Telgraf ve Beyannameleri, C: 4, Ankara, 1964.

Cebesoy, Ali Fuat, Milli Mücadele Hatıraları, İstanbul, 1953.

Davutoğlu, Ahmet, Stratejik Derinlik, İstanbul: Küre 2001.

Duru, Orhan, Amerikan Gizli Belgelerinde Türk Kurtuluş Yılları, İstanbul, 1978.

Fromkin, David, Barışa Son Veren Barış, İstanbul, 1989.

Karabekir, Kazım , İstiklal Harbimiz, İstanbul, 1988.

Lazarev, M.S., Emperyalizm ve Kürt Sorunu (1917-1923), (Çev. Mehmet Demir), Ankara, Özge, 1989. 
Mango, Andrew, Atatürk, İstanbul, Sabah, 1999.

Mutluçăg, Hayri, "Sivas Kongresi'nin Tutanak ve Kararları, VI”, Belgelerle Türk Tarihi

Dergisi, (BTTD) Say1: 67-68, 1973.

Öke, Mim Kemal, Mosul - Kürdistan Sorunu 1918-1926, İstanbul: İz, 1995.

Ortaylı, İlber, “Osmanlı İmparatorluğu’nda Arap Milliyetçiliği”, TCTA, C: 4, İstanbul, 1985.

Ortaylı, İlber, “Osmanlı İmparatorluğu'nda Millet”, Tanzimat'tan Cumhuriyet'e Türkiye Ansiklopedisi (TCTA), C: 4, İstanbul, İletişim, 1985.

Özdemir, Bülent, Süryanilerin Dünü Bugünü, Ankara, TTK, 2009.

Shaw, Stanford, “Osmanlı İmparatorluğu’nda Azınlıklar Sorunu”, TCTA, C: 4

Şimşir, Bilal, Lozan Telgrafları I (1922-1923), Ankara, TTK, 1990.

Tanör, Bülent, Türkiye’de Yerel Kongre Íktidarları, İstanbul, 1992.

Tansel, Selahattin, Mondros'tan Mudanya'ya Kadar, C: I, İstanbul, MEB, 1991.

Tunaya, Tarık Zafer, Türkiye’de Siyasal Partiler, C: II, İstanbul, 1986.

Turan, Şerafettin, Türk Devrim Tarihi, 2. Kitap, Ankara, 1992.

Ulubelen, Erol, İngiliz Gizli Belgelerinde Türkiye, İstanbul, Cumhuriyet, 2006, s. 179. (Belge no: 288) 